\title{
Consciously Transfusion of Blood Products. Systematic Review of Indicative Factors for Blood Components Infusion's Trigger
}

\author{
Ricardo Bittencourt, TEA ${ }^{1}$, José Costa, TSA ${ }^{2}$, José Eduardo de Oliveira Lobo, TSA ${ }^{3}$, Fábio Costa Aguiar, TEA 4
}

\begin{abstract}
Summary: Bittencourt R, Costa J, Lobo JEO, Aguiar FC - Consciously Transfusion of Blood Products. Systematic Review of Indicative Factors
\end{abstract} for Blood Components Infusion's Trigger.

Background and objectives: With the surgical and anesthetic technology advance the indications for intervention are expanding, as well as the need for blood transfusions. Because of its great scientific value, the content to be exposed is subject for endless discussions that provide different guidelines in various clinical and laboratory aspects. The objective of this review is to determine the clinical, laboratorial, and monitoring signs that should guide blood transfusion initiation, avoiding any risk and unnecessary use of resources, as well as the delay on starting therapy, determining tissue hypoxia and its corollaries.

Content: Scientific articles of clinical trials and reviews were used to range various subjects approached in the present content. These subjects were divided according to clinical and laboratorial aspects. Once the described search finished, 2,608 papers were identified, but only 17 original references were selected by inclusion criteria.

Conclusions: Literature is unclear about clinical criteria on the ideal moment to begin the transfusion therapy in order to optimize the relations $\mathrm{risk} /$ and cost/benefit. Studies show that there is no significant difference of oxygen supply $\left(\mathrm{O}_{2}\right)$ in a comparison of hemoglobin $(\mathrm{Hb})$ levels between 6 and 10 g.dL-1, mainly by reduced blood viscosity, facilitating the vascular flow to tissues. However, there is a tendency to recommend the transfusion trigger (TT) when it reaches low values as 6-7 g. $\mathrm{dL}^{-1}$. This same tendency indicates that red blood cells should never be administered with $\mathrm{Hb}$ levels $>10$ g.dL ${ }^{-1}$, except in special situations.

Keywords: Anemia; BloodTransfusion; Cell Hypoxia.

C2012 Elsevier Editora Ltda. All rights reserved.

\section{INTRODUCTION}

With the advances in surgical and anesthetic technologies, indications for intervention, and the need for blood transfusions expanded. Because of its great scientific value, this subject provides different guidelines in clinical and laboratory aspects.

The main objective of perioperative transfusion therapy is to reduce morbidity and mortality associated to inadequate $\mathrm{O}_{2}$ tissue supply during a procedure ${ }^{1}$. Better understanding of

Received from the Hospital Naval Marcilio Dias, Brazil.

1. Anesthesiologist, Maternity Carmela Dutra, Santa Catarina

2. Responsible, CET, Anesthesiology Clinic of Hospital Naval Marcílio Dias

3. Co-responsible, CET, Anesthesiology Clinic of Hospital Naval Marcílio Dias

4. Responsible, Pain Services, Hospital Naval Marcílio Dias

Submitted on April 1, 2011.

Approved on August 3, 2011

Correspondence to:

Ricardo Bittencourt, MD

Maternidade Carmela Dutra

Centro Cirúrgico, Serviço de Anestesiologia

Rua Irmã Benwarda, 208, 2 Andar

Centro

88015270 - Florianópolis, SC, Brazil

E-mail: ricardob22@hotmail.com the $\mathrm{O}_{2}$ transportation, the physiopathology of anemia and the coagulation mechanism allows a reassessment of the real need for transfusion nowadays ${ }^{2}$. Therefore, indications, contraindications, and complications of blood products infusion are essential for the accurate decision and to promote advantageous cost/benefit and risk/benefit relations. These relations refer respectively to the institution and the binomial medical-staff/patient, as the use of blood and its derivatives are rescuing measures in certain well-specified cases, but involve complex administrative logistics and possible risks to the patient's health ${ }^{3}$.

This research's hypothesis is that nowadays, even in metropolitan areas, there is an anticipation in the blood transfuse decision. The objective is to determine clinical, laboratorial and monitoring signs that should guide the blood transfusion initiation, avoiding risk and waste of resources, as well as the delay on initiating the therapy, leading to tissue hypoxia and its corollarie ${ }^{4}$.

\section{METHOD}

Systematic review of original scientific articles, including clinical trials and reviews, on various subjects approached in the present text were divided into guidelines for laboratorial and clinical aspects. Search strategy based itself on the database 
Medline (1970-2009). References of elected original articles that met the inclusion criteria were also analyzed in order to find articles that were not identified by the initial search.

The primary variables adopted in this review were: 'transfusion trigger' (TT), 'anemia', 'blood transfusion', 'blood products', 'hemodilution', 'blood replacement', 'lactate', 'pyruvate', and 'anaerobic metabolism'.

\section{RESULTS}

Once the described search finished, 2,608 papers were identified, but only 17 original references were elected by the inclusion criteria.

Inaba ${ }^{5}$, in an article on TT intraoperative, concludes that the minimum demand to maintain an adequate supply of $\mathrm{O}_{2}$ is $12 \mathrm{~mL} \cdot \mathrm{kg}^{-1} \cdot \mathrm{min}^{-1}$, and it mentions the United States of America resolution (1988), which determines the surgical transfusion trigger and hemoglobin at $7 \mathrm{~g} . \mathrm{dL}^{-1}$, except for cardiac patients.

Von Bormann et al. ${ }^{6}$ determined that under normal blood volume, patients support low hematocrit at $20 \%$ due to lower viscosity and consequent blood velocity increase. They report that patients who refused to receive blood transfusions - such as Jehovah's Witnesses - shown up to $11 \%$ hematocrit during cardiopulmonary bypass (CPB). Their mortality results were similar to patients who decided to receive blood products in order to increase $\mathrm{O}_{2}$ supply in cardiac surgery. Authors concluded that hemoglobin $(\mathrm{Hb})>9 \mathrm{~g}^{\mathrm{dL}}{ }^{-1}$ does not necessarily increase $\mathrm{O}_{2}$ supply to tissues. Another recent report suggests that there is no evidence that mild anemia impairs healing or increases bleeding or hospitalization period of time ${ }^{7}$.

Weil et al. ${ }^{8}$, in an article on clinical studies of lactate and pyruvate as severity indicators of acute circulatory deficit, demonstrated that lactate is the laboratorial indicator that keeps the closest correlation with the imbalance between $\mathrm{O}_{2}$ supply and $\mathrm{O}_{2}$ consumption, considering lactate $>2 \mathrm{mmol}^{-\mathrm{L}^{-1}}$ for surgical patients as reference. Mortality increases from $10 \%$ to $90 \%$ when lactate goes from 2.1 to $8 \mathrm{mmol}^{-\mathrm{L}^{-1}}$.

Pyruvate ratio with $\mathrm{O}_{2}$ accumulated debt was not statistically significant in any partial studied $(p>0.10)$. As final result, lactate failed to predict mortality in only $11 \%$ of the cases when compared to the pyruvate failure $(21 \%)$ and its variables; excess lactate $(14 \%)$ and lactate/pyruvate ratio $(23 \%)$.

Smith et al. ${ }^{9}$ analyzed excess basis as prognosis for patients admitted into intensive care, correlating values $<-4$ with lactate $>1.5 \mathrm{mmol}^{-\mathrm{L}^{-1}}$.

In a study of Mekontso-Dessap et al. ${ }^{10}$, they experienced $\mathrm{O}_{2}$ and $\mathrm{CO}_{2}$ variables in monitored patients with pulmonary artery catheter (PAC). They assessed that among all possible parameters the relationship between the $\mathrm{CO}_{2}$ arteriovenous difference and $\mathrm{O}_{2}$ arteriovenous content $\left(\triangle \mathrm{PCO} / \mathrm{C}(\mathrm{a}-\mathrm{v}) \mathrm{O}_{2}\right)$ is the one that best correlates to the anaerobic metabolism. In addition to that, the value from 1.4 presented $79 \%$ sensitivity and $84 \%$ specificity with $86 \%$ positive and $80 \%$ negative predictive values for hyperlactatemia (lactate $>2 \mathrm{mmol}^{-\mathrm{L}^{-1}}$ ). The $\mathrm{O}_{2}$ tissue uptake $\left(\mathrm{VO}_{2}\right)$ was lower in "lactate+" group then in the "lactate-" group (109 \pm 41 vs $127 \pm 32 ; \mathrm{p}<0.01)$, with no significant difference in the other parameters collected by $\mathrm{CAP}$, such as venous saturation oxygen $\left(\mathrm{SvO}_{2}\right)$, tissue oxygenation supply $\left(\mathrm{DO}_{2}\right), \mathrm{C}(\mathrm{a}-\mathrm{v}) \mathrm{O}_{2}$ or oxygen extraction rate $\left(\mathrm{O}_{2} \mathrm{ER}\right)$. The $\triangle \mathrm{PCO}_{2}$ was higher in "lactate+" group than in "lactate-" group ( $3.8 \pm 2.0$ vs $6.1 \pm 2.7 ; p<0.001)$. In a similar way $\triangle \mathrm{PCO}_{2} / \mathrm{C}(\mathrm{a}-\mathrm{v}) \mathrm{O}_{2}$ was higher in the "lactate+" in comparison to the "lactate-" $(2.0 \pm 0.9$ vs $1.1 \pm 0.6 ; p<0.0001)$.

Table I shows other variables, relating to the confidence intervals:

Hébert et al. ${ }^{11}$, comparing liberal transfusion $\left(\mathrm{Hb}<10 \mathrm{~g} \cdot \mathrm{dL}^{-1}\right)$ with restrictive transfusion $\left(\mathrm{Hb}<7 \mathrm{~g} \cdot \mathrm{dL}^{-1}\right)$ in critical patients, concluded that the trigger "10-30" previously proposed was inefficient. It leads to $54 \%$ abusive use of blood products and millions of dollars annually spent in the U.S., increasing transfusion therapy risks. In this study, increased mortality was measured after 30 days in critically ill patients in the liberal transfusion group ( $18.7 \%$ vs $23.3 \%, p=0.11$ ), with higher mortality during hospitalization as well $(22.2 \%$ vs $28.1 \%$, $p=0.05$ ).

Vincent et al. ${ }^{3}$ in a prospective observational study of transfusion in critically ill patients found no direct relationship between the number of transfused RBCs units and the mortality rates, mainly related to immunosuppression inherent in blood transfusion.

Table I- $\mathrm{O}_{2}$ and $\mathrm{CO}_{2}$ Variables

\begin{tabular}{lll}
\hline Parameter & Correlation Coeff. (r) & $p$ \\
\hline Sat. ${ }_{2}$ & -0.01 & 0.94 \\
$\mathrm{SvO}_{2}$ & 0.14 & 0.09 \\
$\mathrm{DO}_{2}$ & 0.13 & 0.1 \\
$\left.\mathrm{C}_{2} \mathrm{a}-\mathrm{v}\right) \mathrm{O}_{2}$ & -0.26 & 0.01 \\
$\mathrm{VO}_{2}$ & -0.35 & $<0.0001$ \\
$\mathrm{O}_{2} \mathrm{ER}$ & -0.16 & 0.05 \\
$\mathrm{PaCO}_{2}$ & -0.26 & $<0.01$ \\
$\Delta \mathrm{PCO}_{2}$ & 0.28 & $<0.01$ \\
$\mathrm{PvCO}_{2}$ & -0.2 & 0.01 \\
$\Delta \mathrm{PCO}_{2} / \mathrm{C}(\mathrm{a}-\mathrm{v}) \mathrm{O}_{2}$ & 0.57 & $<0.0001$ \\
\hline
\end{tabular}

\section{DISCUSSION}

Physiopathology that responds by circulatory shock due to bleeding/anemia is a critical reduction in the transport of vital nutrients and metabolic requirements of tissues and organs. When there is circulation irregularity, secondary to reduced blood volume (BV), $\mathrm{O}_{2}$ supply becomes scarce determining extensive cell dysfunction and ischemic injury. Under normal conditions, $\mathrm{DO}_{2}-\mathrm{O}_{2}$ amount carried to tissue per minute - remains approximately 950 to $1,150 \mathrm{~mL}$. $\mathrm{min}^{-1}$. It is represented by the product of cardiac output (C.O.) with the arterial oxygen content $\left(\mathrm{CaO}_{2}\right)$ multiplied by 10 [C.O. $\times \mathrm{CaO}_{2} \times 10$ ]. The $\mathrm{VO}_{2}-\mathrm{O}_{2}$ body consumption in one minute - is around 200 to $250 \mathrm{~mL}^{\mathrm{min}} \mathrm{m}^{-1}$, and is calculated by multiplying the C.O. by the $\mathrm{O}_{2}$ arteriovenous difference $\left(\mathrm{C}(\mathrm{a}-\mathrm{v}) \mathrm{O}_{2}\right)$ [C.O. $\times \mathrm{C}(\mathrm{a}-\mathrm{v}) \mathrm{O}_{2}$ ]. In resting condition, $\mathrm{O}_{2}$ consumption represents only $25 \%$ of total supply 12 . 
In an early deficit stage, the main mechanism to compensate supply drop is the fraction increase of the $\mathrm{O}_{2}$ extraction by tissues, that normally ranges between $22 \%$ to $30 \%$. As heart muscle has a high metabolism, the extraction rate is usually above $70 \%$, not benefiting from the extraction ratio increase during the $\mathrm{O}_{2}$ deficit. In normal coronary arteries, this condition is offset by vasodilation with increased blood flow (BF) to the myocardium. However, on coronary artery disease, this expansion capacity is reduced, explaining the trigger transfusion displacement for $\mathrm{Hb}=10 \mathrm{~g} \cdot \mathrm{dL}^{-1}$.

In theory, when the $\mathrm{DO}_{2}$ is reduced to $8 \mathrm{~mL} \cdot \mathrm{kg}^{-1} \cdot \mathrm{min}^{-1}$, the $\mathrm{VO}_{2}$ is also reduced. This reduction during shock is closely related to the presence of lactic acidosis, and it consequently affects the survival rate.

As the opportunity to measure metabolic requirements is usually difficult to set during surgery and in poor hemodynamic conditions, there are practical methods to determine the indirect $\mathrm{O}_{2}$ supply and consumption. During the anaerobic metabolism, the aerobic oxidation of the tricarboxylic acid is blocked, and the oxidation of nicotinamide adenine dinucleotide $\left(\mathrm{NADH}_{2}\right)$ to $\mathrm{NAD}$ is controlled by the absence of $\mathrm{O}_{2}$. Thus, in the presence of lactate dehydrogenas it tilts the reaction favoring the accumulation of lactate, an element closely related to the shock severity ${ }^{8}$. Reductions in $\mathrm{CaO}_{2}$ because of blood loss need a compensatory increase in one of the $\mathrm{DO}_{2}$ formula variables for the suitable supply. This compensatory increase results from the C.O. elevation via the peripheral vascular resistance reduction due to lower blood viscosity.

Analysis of the selected articles concludes that TT is essentially personal, varying according to individual characteristics (age, physical status, presence or absence of cardiovascular co-morbidities, lung and kidney diseases, and clinical signs of pre-, peri- and postoperative ${ }^{13}$ ) in composition with laboratorial indicators properly evaluated $7-9,10,14$.

Blood products transfusion should be based on criteria and without delay. However, once it is indicated, the transfusion professional must do it according to basic physiology, such as shock, energy generation by anaerobic mechanism, and concisely assessment of hemodynamic variables and tissue oxygenation, as well as the precise analysis of arterial and venous gases $3,8-10,14,15$.

The good knowledge of resulting changes from blood storage is essential. These changes include: thrombocytopenia, reduction of coagulation factors $\mathrm{V}$ and VIII, metabolic acidosis by lactic acid increase and bicarbonate decrease, hyperpotassemia, hemolysis and decreased levels of ATP, and 2.3 DPG, with a resulting change in the dissociation curve and increased hemoglobin affinity for $\mathrm{O}_{2}$, which hinders its release to tissues. The transfused blood cells synthesize 2.3 DPG normalizing the release to tissues after 12 to 36 hours approximately. It shows that the stored red cells infusion does not increase the immediate supply of $\mathrm{O}_{2}$ to tissues ${ }^{2,3,15}$.

The evaluation should begin in the preoperative period with a thorough review of medical records, accompanied by a detailed anamnesis in search of pathologies - e.g. cardiovascular, nephropathy and coagulopathy - and regular use of medications, vitamins or herbs that may affect coagulation, which may ultimately influence the TT. One should also inquire about previous exposure to drugs such as aprotinin or protamine, for potential allergic reactions. The complement to this strategy is the adoption of laboratory tests, $\mathrm{Hb}$ measurement, hematocrit and coagulation profile, which is suggested in the literature for predicting the need for hematologic support 2,13 .

When there are coagulation problems related to the interference of factors II, VII, IX and X as in the case of warfarin 2,13, the available drugs include antifibrinolytics, acid-epsilon-amino caproic acid, tranexamic acid and vitamin $\mathrm{K}$.

Preventive measures for the allogeneic transfusion include the early blood collection 21, 14 and 7 days before surgery. Pharmacological stimulation of erythropoiesis with erythropoietin at a dose of $600 \mathrm{Ul}^{.} \mathrm{kg}^{-1}$ must occur in this same collection interval, including the days of surgery $2,4,13$, hypotensive anesthesia and acute normovolemic hemodilution, when blood loss is expected to exceed $20 \%$ of volume ${ }^{2,16}$.

This method's compensatory mechanisms include an increase in DC, changes in blood rheological characteristics, and deviation of hemoglobin saturation curve to the right, with increased $\mathrm{O}_{2}$ extraction by tissues. The intraoperative blood recovery is another valid strategy to prevent allogeneic transfusion. This technique is indicated 1) for blood losses estimated as more than $20 \% \mathrm{BV}$; 2) surgical procedures requiring transfusion in more than $10 \%$ of patients; 3 ) surgeries averaging over onetransfusion unit; and 4) patients who cannot or refuse to have allogeneic transfusions. The contraindications are often by contamination of the recovered blood. There are studies in the literature showing a higher incidence of metastasis after intraoperative blood recovery in oncology surgeries due to non removal of tumor cells by this method ${ }^{2,13}$.

Recommendations for intraoperative management include direct visualization and approach with the surgical team monitoring microvascular excessive blood loss; monitoring of inadequate perfusion and oxygenation of vital organs by conventional signs such as heart rate (HR), blood pressure (BP), urinary output, $\mathrm{SpO}_{2}$ and change in systolic blood pressure (SBP), which measures the difference in SBP between the inspiratory and expiratory phase of mechanical ventilation. Variations above $10 \mathrm{~mm} \mathrm{Hg}$ are suggestive of hypovolemi. Special monitoring tests include echocardiography, measurement of gastric mucosal $\mathrm{pH}$, mixed venous oxygen saturation and blood gas analysis, but they are limited.

In addition to these parameters, indications for transfusion based on laboratorial values such as serial plasma $\mathrm{Hb}$ levels, generally indicated with $6 \mathrm{~g} \cdot \mathrm{dL}^{-1}$, should be maintained, especially in acute anemia. $\mathrm{Hb}$ levels $>10 \mathrm{~g}^{\mathrm{dL}}{ }^{-1}$ are usually enough and transfusion is usually not recommended, as the $\mathrm{O}_{2}$ concentration can remain constant between that 10 and 15 g.dL-17. The indications for the intermediate values are based on evidence of potential or actual ischemia, bleeding magnitude, and risk factors for complications of inadequate oxygenation and perfusion, including low cardiopulmonary reserve and high $\mathrm{VO}_{2}{ }^{2,13}$.

The handling of intraoperative coagulopathy includes visualization of the surgical field, blood aspiration, drain losses, gauze and bandages. It should also contemplate the laboratory test of the coagulation profile, supported by the literature. 
Platelet transfusion is always considered after its blood dosing, and functional test are applied when there is impairment suspicion, such as in the use of antiplatelet agents. The infusion of platelets is rarely indicated for blood levels over $100.10^{3} \cdot \mathrm{mm}^{-3}$ and is generally indicated for levels below $50.10^{3} \cdot \mathrm{mm}^{-3}$. The decision to transfuse between these values should be based on the possibility of dysfunction and surgeries in confined spaces, as eye and brain. The prophylactic transfusion for thrombocytopenia secondary to platelet destruction is ineffective and contraindicated 2,13 .

Fresh frozen plasma (FFP) can be considered after coagulation tests (PT, INR and PTT), but never being infused if these tests results are normal. The indications for surgery are limited to: 1) treatment of excessive microvascular bleeding with APT if evidence is greater than 1.5 times the standard reference, ISI is greater than 2, and TTP is two times greater than the reference; 2) correction of microvascular bleeding secondary to deficiency of coagulation factors in patients transfused more than one with BV $\left(70 \mathrm{~mL} \cdot \mathrm{kg}^{-1}\right)$, considering that coagulation tests were not obtained immediately; 3 ) urgent reversal of warfarin with dose between 5 and $8 \mathrm{~mL} . \mathrm{kg}^{-1}$; 4) correction of unknown clotting factor, or the moment when the specific concentrate is not available; and 5) resistance to heparin (antithrombin deficiency III) in patients requiring heparin. FFP is never indicated with osmotic intention or as fluid replacement. Usually the dose 15 to $20 \mathrm{~mL}^{\mathrm{kg}}{ }^{-1}$ is required to achieve from $20 \%$ to $30 \%$ of factors, enough to normalize the clotting tests ${ }^{2,13,17}$. The use of FFP to treat dilutional coagulopathy massive transfusion in the absence of diffuse microvascular bleeding is not supported in the literature and may not even be necessary to replace 15 to 20 red blood cells concentrate.

Cryoprecipitate transfusion is rarely indicated if the fibrinogen count is over $150 \mathrm{mg} \cdot \mathrm{dL}^{-1}$, being recommended to: 1) values between 80 and $100 \mathrm{mg} \%$ in the presence of evident microvascular bleeding; 2) microvascular bleeding in patients transplanted with large volumes, when the fibrinogen level cannot be measured immediately; and 3) patients with congenital fibrinogen ${ }^{13}$. The use of desmopressin and local haemostatics is indicated ${ }^{13}$ (Table II).

Measuring the blood lactate is a practical and indirect assessment method of tissue oxygenation deficit, which is extremely useful in orientating transfusion therapy. Lactate is the final product of anaerobic glycolysis, and is usually produced at a rate of $1 \mathrm{mmol}^{\mathrm{kg}} \mathrm{kg}^{-1} \cdot \mathrm{h}^{-1}$, with pyruvate as the sole source. This reaction may be expressed as:

$$
\text { Glucose }+2 \mathrm{ATP}+\mathrm{H}_{2} \mathrm{PO}_{4}=>2 \text { Lactate }+2 \mathrm{ADP}+2 \mathrm{H}_{2} \mathrm{O}
$$

Generated lactate can be used as primary substrate for oxidation (energy source), allowing the conclusion that the anaerobic metabolism is the major source of serum lactate.

Although lactate is an excellent substrate for anaerobic analysis, this parameter should be analyzed carefully, noting that other conditions can also raise it. However it does not mean $\mathrm{O}_{2}$ deprivation, as in the presence of sepsis, infusion of adrenaline, thiamine deficiency, respiratory or metabolic alkalosis, hepatic and nitroprusside poisoning ${ }^{14}$. Although these
Table II - Use of Desmopressin and Local Hemostatics

\begin{tabular}{lll}
\hline $\begin{array}{l}\text { Coagulation } \\
\text { Factor }\end{array}$ & $\begin{array}{l}\text { Concentration for } \\
\text { hemostasis }\end{array}$ & $\begin{array}{l}\text { Average life span of } \\
\text { factor }\end{array}$ \\
\hline I - fibrinogen & $1 \mathrm{~g} \cdot \mathrm{L}^{-1}$ & 4 to 6 days \\
II - prothrombin & $0.4 \mathrm{UI} \cdot \mathrm{mL}^{-1}$ & 2 ato3 days \\
V & 0.1 to $0.15 \mathrm{UI} . \mathrm{mL}^{-1}$ & 12 hours \\
VII & 0.05 to $0.1 \mathrm{UI} \cdot \mathrm{mL}^{-1}$ & 2 to 6 hours \\
VIII & 0.1 to $0.4 \mathrm{UI} . \mathrm{mL}^{-1}$ & 8 to 12 hours \\
IX & 0.1 to $0.4 \mathrm{UI} \cdot \mathrm{mL}^{-1}$ & 18 to 24 hours \\
X & 0.1 to $0.15 \mathrm{UI} \cdot \mathrm{mL}^{-1}$ & 2 days \\
XI & $0.3 \mathrm{UI} . \mathrm{mL}^{-1}$ & 3 days \\
XII & - & - \\
\hline
\end{tabular}

conditions may confuse the assessment, it should be borne in mind that in the presence of hyperlactatemia in good tissue perfusion, the buffer mechanism is able to compensate the decrease in $\mathrm{pH}$, not being possible during hypoperfusion ${ }^{9}$.

Even if the lactate is a pyruvate substrate, in addition to other lactate derived as lactate excess and the relation L/P, they do not have statistical significance to establish a relation with the mortality.

Another parameter that is related to blood lactate concentration is Excess Base (EB). According to Smith et al. ${ }^{9}$, there is a relation between base excess and blood lactate by tissue hypoxia and dysoxia, being a reasonable parameter for early fluid-restitution/transfusion if other indicators also point out to this type of deficit. Severity of excess base should be based according to the following classification: mild ( -3 to -5$)$, moderate $(-6$ to -14$)$ and severe $(>15)$.

Under conditions of tissue hypoxia, total $\mathrm{CO}_{2}$ production is greater than the $\mathrm{O}_{2}$ consumption. That is because $\mathrm{CO}_{2}$ production under anaerobic conditions occurs primarily by the buffering of excess protons generated by the hydrolysis of bicarbonate ATP.

\section{CONCLUSION}

There are no well defined clinical criteria to indicate the ideal moment for transfusion therapy initiation. Arbitrary values are inadequate to define when the hemotherapy is indicated. Each patient must be individually evaluated, with specific strategies for bleeding prevention until components replacement. Therapy should not be indicated with hemoglobin above $10 \mathrm{mg}^{\mathrm{dL}-1}$, unless special situations in which there is no significant difference in the $\mathrm{O}_{2}$ supply when $\mathrm{Hb}$ levels between 10 and $15 \mathrm{~g}$. $\mathrm{dL}^{-1}$ are compared. The association of clinical and laboratory indicators of tissue dysoxia seems to be a good strategy for assessing the need for transfused blood, being generally correlated with $\mathrm{Hb}$ levels of $6 \mathrm{mg}^{\mathrm{dL}}{ }^{-1}$. For intermediate values, individual assessment for each patient is more apropriate.

\section{ACKNOWLEDGEMENTS}

Special thanks to Dr. Mário José da Conceição, for his kind collaboration with patient reviews, constructive criticism and more than helpful and brilliant opinions. 
9. Smith I, Kumar P, Molloy S - Base excess and lactate as prognostic indicators for patients admitted to intensive care. Intensive Care Med, 2001;27:74-83

10. Mekontso-Dessap A, Castelain V, Anguel $\mathrm{N}$ et al. - Combination of venoarterial $\mathrm{PCO} 2$ difference with arteriovenous $\mathrm{O} 2$ content difference to detect anaerobic metabolism in patients. Intensive Care Med, 2002;28:272-277.

11. Hébert PC, Wells G, Blajchman MA et al.; Transfusion Requirements in Critical Investigators For the Canadian Critical Care Trials Group - A multicenter, randomized, controlled clinical trial of transfusion requirements in critical care. New Eng J Med, 1999;340(6):409-417.

12. Felippe HS, Sannuti Pais RG, Cassano AC, Cozza D, Vargas RAA - Monitorização com cateter de Swan-Ganz: aspectos clínicos. Arq Bras Med Naval, 1999;60(01):45-67.

13. American Society of Anesthesiologists Task Force on Blood Component Therapy - Practice guideline for blood component therapy. Anesthesiology, 1996;84:732-747

14. Knobel E, Akamine N, Junior CJF, Silva E - Terapia intensiva - Hemodinâmica. Rio de Janeiro: Editora Atheneu, 2003.

15. Barash PG, Cullen BF, Stoelting RK - Clinical anesthesia. $5^{\mathbf{a}}$ edição. Lippincott Williams \& Wilkins, 2006.

16. Weiskopf RB - Efficacy of acute normovolemic hemodilution assessed as a function of fraction of blood volume lost. Anesthesiology, 2001;94:439-446.

17. Diretoria Colegiada da Agência nacional de Vigilância Sanitária - Diretrizes para o uso de plasma fresco congelado - PFC de plasma vírus inativo. Resolução-RDC № 10, de 23 de Janeiro de 2004 - DOU de 20/02/2004.

\section{REFERÊNCIAS/REFERENCES}

1. Choy YC, Lim WL Ng SH - Audit of Perioperative Blood Transfusion. Med J Malaysia, 2007;62:299-302.

2. Silva ED, Novo RB - Uso crítico de sangue e seus derivados. Atual Anestesiol SAESP, 1997;3:88-107.

3. Vincent JL, Baron JF, Reinhart K et al. - Anemia and blood transfusion in critically III patients. JAMA, 2002;288:1499-1507.

4. Stulberg BN, Zadzilka JD - Blood management issues. Using blood management strategies. J Arthroplast, 2007;22(Suppl4):95-98.

5. Inaba S - Allogenic blood transfusion for surgery. Nihon Geka Gakkai Zasshi, 2005;106(1):13-17.

6. Von Bormann B, Aulich S - Critical hematocrit from the viewpoint of the clinician. Beitrage zur Infusionstherapie. 1992;30:216-223 [discussion 247-64].

7. Stoelting RK, Miller RD - Bases de anestesia. 4a edição. Editora Roca, 2004.

8. Weil MH, Afifi AA - Experimental and clinical studies on lactate and pyruvate as indicators of the severity of acute circulatory failure (Shock). Circulation (American Heart Association), 1970;41:9891001. 